\title{
Physico Chemical Assessment of Borehole Waters in Ovim, Isiukwuato Lga, Abia State, Nigeria.
}

\author{
${ }^{1}$ N.M.Mgbemena, ${ }^{2}$ G.A. Obodo, ${ }^{3}$ N.A. Okonkwo and V.I Onwukeme \\ ${ }^{I}$ Department Of Chemistry Michael Okpara University Of Agriculture Umudike Abia State Nigeria \\ ${ }^{2}$ Department Of Industrial Chemistry Imo State University Owerri,Imo State Nigeria \\ ${ }^{3}$ Department Of Industrial Chemistry Madonna University Elele Rivers State Nigeria \\ Department Of Pure And Industrial Chemistry,Nnamdi Azikiwe University Awka,Nigeria
}

\begin{abstract}
The physico-chemical and metal analysis of five different borehole waters in Ovim Isuikwuato Local Government Area, Abia State were analysed to ascertain the quality of the water used in Ovim. Five different samples were collected from each borehole and a composite sample made. The parameters determined include temperature (27.00-29.50), $\mathrm{pH}$ (5.5-7.8). total dissolved solid mg/l (11.50 -30.53), conductivity (88.00 -129.90), turbidity (1.25-2.94). total hardness (12.70-231.6) total alkalinity (70.60 83.30), chloride (3.11 -6.17), sulphate (0.44 - 1.86), nitrate, colour, odour and taste. Metals like potassium, calcium, magnesium, copper, iron, manganese, zinc, lead and cadmium, were also determined. There was no lead and cadmium observed in the samples. The results obtained when compared with the standard of WHO and NAFDAC were found to be within the limits of these. Bodies therefore making the waters safe and free for drinking and other domestic purposes.
\end{abstract}

Key words: Ground water, contamination, parameter

\section{Introduction}

Water is a chemical substance essential to all known forms of life. It is referred to as the liquid state of the hydrogen-oxygen compound $\left(\mathrm{H}_{2} \mathrm{0}\right)$. About 1,460 teratonnes of water cover over $71 \%$ of the earth's surface (oceans and other water bodies). There is about $1.7 \%$ of water below the ground in aquifers and $0.001 \%$ in the air as vapours (1). All living things on earth depend on water for their water. Water has been ranked by experts as second to oxygen as essential for life (2). About $70 \%$ of the body mass of an average adult human being is made up of water. Water makes up a large part of the protoplasm and is the medium in which chemical reactions take place in the body. It is important in the transportation of excretory products, blood and hormones (3). Water is of immense benefit to man, adequate care should be taken when assessing water intake and usage. The best standard of purity is required for drinking water as the water we drink is got from different sources like wells, streams, lakes, rivers (surface water), ground water (boreholes) etc.

Ground water has various advantages over surface water as it is not exposed to water pollutants associated with surface waters. It is in view of this that the World Health Organization recommended that drinking water supplies should be well analyzed based on their contamination or pollution level (4). Very few people in small towns have access to safe water supply. Only about 5 percent get water from protected ground sources through boreholes $(5,6)$. Some agencies argued that it is not sufficient merely to have access to water in adequate quantities, the water also needed to be of adequate quality to maintain good health (6). Such water must be free from toxic biological, physiological and chemical contaminations. The widespread reports on pollutants in groundwater have increased in recent years and have resulted in increased public concern about the quality of groundwater. The importance of potable water, both for domestic and industrial uses, has created concern for water quality analysis $(7,8)$. Groundwater bodies are prone to contamination from both anthropogenic and natural activities (9). Boreholes, though more protected as a result of inherent chemical constituents of permeable rocks through which the water flows $(10,11)$ can limit the quality of the water as they may have dissolved impurities which came from rock and sand strata through which the water flowed or passed. The seepage of waste buried underground such as pit toilets or leachate from fertilizer applications and debris from erosion can produce deleterious effects on ground water quality especially in Isiukwuato, as it is one of the areas in Abia State with very high erosion menace and are mostly farmers.

Water quality monitoring is very necessary as pollution of water affects both quality of water and health of the consumers. This study was carried out to determine the physico-chemical properties of five different boreholes in Ovim in Isiukwuato in order to asses the portability and usability of their borehole water as domestic water supply. Ovim is chosen for the research as many workers in the Local Government and students of Abia State University reside there. 


\section{The Study Area}

The study area (Fig 1) Ovim, Isiukwuato LGA, of Abia State comprises of five autonomous communities namely Amaeke, Amune, Obai, Ohanja and Ohuroohu. It is located in Abia North senatorial zone. It has a double maxima rainfall peaks in July and September. The cultural life of the people (Ovim) are farming, they produce yams, cocoyam, cassava. The geology of Ovim, Isiukwuato LGA (Fig 2) falls within the Nsukka formation (upper coal measures). It has the following litho logic and hydrolith logic characteristics altering sequences of shade and sandstones with coal seams, clays, carbonaceous shale's, subordinate limestone, silt stone etc.

\section{Experimental Method}

Groundwater samples were collected individually from 5 boreholes. Water samples from the boreholes were pumped out using existing infrastructure for over 10 minutes before samples were collected from the point of casing and covered immediately using 2 litre polyethylene cans which were rinsed will 1:1 $\mathrm{HCl}$, deionized water properly labeled. The sample containers were rinsed with the water samples at the point of collection. Five samples were collected from each site at the interval of two hours and mixed together to make a composite sample. The water samples were immediately carried to the labotary and the following parameters determined, general appearance, odour, taste, $\mathrm{pH}$. conductivity, temperature using the method described by Gaines and Greenbarg $(12,13) \mathrm{pH}$. was determined using microprocessor $\mathrm{pH}$ meter and conductivity using Hanna electrical conductivity meter.

Other various standard methods were used to determine the other parameters like total solids, total dissolved solids, turbidity, alkalinity, total hardness, magnesium and calcium were measured using EDTA titrimetric methods. The heavy metals were determined using Atomic Absorption spectrophotometric methods. Some blanks were run for all the analysis performed. Chloride was determined by direct reading titrator (14), sulphate was determined by turbidimetric method, nitrate using phenodisulphonic acid method.

\section{Results and Discussion}

The results of the physicochemical properties and metal concentrations of the Ovim borehole waters were shown below in Tables 1 and 2 .

Table 1: Mean values of the physicochemical properties of the different boreholes in Ovim

\begin{tabular}{|c|c|c|c|c|c|c|c|}
\hline Parameter & Amaeke & Amune & Obai & Ohanja & Ohuruohu & WHO & NAFADC \\
\hline Temperature ${ }^{0} \mathrm{C}$ & 29.00 & 29.50 & 28.90 & 27.00 & 27.95 & 29.50 & - \\
\hline Total Dissolved solid mg/l & 23.80 & 30.53 & 13.50 & 5.90 & 10.50 & $1000 \max$ & 1000 \\
\hline Conductivity & 87.00 & 112.40 & 179.90 & 79.90 & 88.00 & 15000 & 1000.00 \\
\hline Turbidity & 1.93 & 2.94 & 1.39 & 1.25 & 1.32 & $5 \mathrm{NTU}$ & $5.0 \mathrm{NTU}$ \\
\hline Total Hardness mg/l & 98.60 & 167.60 & 231.6 & 68.80 & 62.70 & 500 & 100 \\
\hline Sulphate & 0.44 & 0.38 & 1.22 & 2.50 & 1.86 & 250 & 50.00 \\
\hline Phosphate & 1.10 & 0.12 & 0.10 & 0.11 & 0.21 & 250 & - \\
\hline Nitrate & 2.33 & 1.33 & 0.72 & 1.32 & 1.02 & 50 & 45 \\
\hline Water Appearance & Clear & Clear & Clear & Clear & Clear & Clear & Clear \\
\hline Colour TCU & 5.80 & 7.40 & 2.30 & 5.10 & 3.70 & 15 & 3.00 \\
\hline
\end{tabular}

Table 2: Metal concentration (mg/l) in the borehole waters

\begin{tabular}{llllllll}
\hline Parameter & Amaeke & Amune & Obai & Ohanja & Ohuruohu & WHO & NAFDAC \\
\hline Potassium & 0.80 & 0.50 & 0.80 & 0.80 & 0.80 & $1.10 \mathrm{mg} / 1$ & - \\
Calcium & 26.50 & 21.00 & 20.00 & 20.60 & 20.50 & $3.75 \mathrm{mg} / 1$ & - \\
Magnesium & 18.00 & 8.30 & 6.00 & 7.00 & 8.30 & 30 & - \\
Copper & 0.32 & 0.30 & 0.30 & 0.27 & 0.00 & $1.0 \mathrm{mg} / 1$ & $1.0 \mathrm{mg} / 1$ \\
Iron & 0.40 & 0.20 & 0.00 & 0.02 & 0.07 & $3.0 \mathrm{mg} 1$ & $0.3 \mathrm{mg} / 1$ \\
Manganese & 0.15 & 0.04 & 0.01 & 0.00 & 0.00 & $0.4 \mathrm{mg} / 1$ & $2.0 \mathrm{mg} / 1$ \\
Zinc & 0.22 & 0.40 & 0.03 & 0.01 & 0.02 & $3.0 \mathrm{mg} / 1$ & $5.0 \mathrm{mg} / 1$ \\
Lead & 0.00 & 0.00 & 0.00 & 0.00 & 0.01 & $0.01 \mathrm{mg} / 1$ & 0.01 \\
Cadmium & 0.00 & 0.00 & 0.00 & 0.00 & 0.00 & 0.003 & 0.003 \\
\hline
\end{tabular}

From the results in Table 1 it can be seen that the water appearance was clear, it was also odourless and tasteless, their values fall within the permissible limit of WHO and NAFDAC regulatory bodies. These could be due to the absence of particles and non accumulation of solids and slits. For colour all the water samples were within the WHO limit and all except Obai (2.3.) range above NAFDAC (3.0). Colour in natural water usually 
results from leaching of organic materials and is primarily the result of dissolved and colloidal humic substances, primarily humic acid and fluvic acid.

However, the overall colour content do not pose any health threat to those that use the water. The $\mathrm{pH}$ ranged from 5.5 (Amaeke) to 7.89 (Ohuruohu). Only Amaeke and Amune had acidic pH, other fell below the WHO and NAFDAC standard of $\mathrm{pH}$ 6.5-8.5. Water is said to be safe if the concentrations of the undesired substances do not exceed the levels set by the regulatory bodies e.g WHO and NAFDAC (15). Conductivity level ranged from 87.00 in Amaeke to 179.00 in Obai. Thus conductivity was far below the standards of the two regulatory bodies and therefore fell within the safe limits for portable water. The low conductivity indicated the presence of some ions in low levels (16). The values for total solid ranged from 6.90 in Ohanja to 31.53 in Amune and total dissolved solids were 5.90 in Ohanja to 30.53 in Amune and still fell below the standards for the regulatory bodies. The values for turbidity also fell within the permissible levels of the regulatory bodies. The values for total alkalinity were also within the permissible level of the regulatory bodies. Total hardness fell within the permissible level of WHO but Amune/167.60 and Obai (231.6) fell far above the permissible level of NAFDAC $(100 \mathrm{mg} / \mathrm{l})$. Soft waters are associated with rickets in children and have been found to be statistically related to high mortality from cardio vascular disease (17). Very hard water is not good for drinking and is associated with rheumatic pains and goiter $(18,19)$. The chloride level of 3.11 to 6.74 , sulphate $0.44-2.50$, phosphate $0.10-1.10$ and nitrate $0.72-2.33$ fell within the permissible limits for drinking waters thus making the water safe for drinking and other domestic activities.

Table 2 showed the results of the metal concentration in Ovim borehole waters. From the results the levels of potassium, calcium, magnesium, copper, iron, manganese and zinc were within the permissible levels of WHO and NAFDAC. There was no lead or Arsenic in the sample of water determined.

\section{Conclusion}

The results of the study have shown that the waters were within the limits of WHO and NAFDAC for potable water and therefore safe for human and animal consumption, subsequently there is need for regular checking of these parameters to ensure the health and safely of the populace and subsequently reduce diseases caused by poor water quality.

\section{References}

[1]. American Public Health Association Standard (2003). Methods for examination of water and waste water $20^{\text {th }}$ edition Washington DC, APHA Pg 20.

[2]. American Society for Testing of Materials (2000). Method for examination of water and waste water. $20^{\text {th }}$ edition ASTM pg 110 .

[3]. Batmanghelidj, F. (2005). Water, a fundamental part of our lives. $2^{\text {nd }}$ edition. Blackwell Science Ltd. Pg 65.

[4]. Bunce, N.J. (2004). Environmental Chemistry $2^{\text {nd }}$ edition, Wuevz Publishing Ltd. Wininnipeg, Canada. Pg $20-25$.

[5]. Federal Ministry of Water Resources and Rural Development Small Towns (1998). Water supply and sanitation programme. Implementation Guidelines. Federal Republic of Nigeria.

[6]. World Health Organization (1996). State of the World Health Report Geneva, Pg 37-48.

[7]. Brandley, D. J.; (1977). Health Aspect of Water Supplies in Tropical Countries Structural Dependence of Flavonoids Interactions with Copper (11) ions. Oklahoma State University. USA. Annual Science Journal 33,78.

[8]. Bauder, J. W. and Vogel, M. P. (1990). Contaminants-likely sources and Hazardous Levels. In Cooperation with Montana Farm Bureau http:/hermes.ecn.purduedu:80001/water. quality/Montana/wq.

[9]. Okuo, J. M.; Okonji, E. J. and Omoyerere, F. R. (2007) Hydrophysiochemical Assement of the Warri Coastal Aquifer, Southern Nigeria, J. Chem Soc. Nigeria 32 (1) Pg 53-64.

[10]. Levision, A. A. (1974). Introduction to Exploration Geochemistry Applied Publishing Company Ltd Pg 80-84.

[11]. Umo, A. E. and Okoye, C. O. B. (2006). Quality of Borehole Waters in Nsukka Area, Enugu State Nigeria. Nigeria Annuals of Natural Sciences 6(2) Pg 121.

[12]. Gaines, B. J. (1993). Applied Water and Spent Water Chemistry. A Laboratory Manual, Van Nostrand Reinhold New York Pg 168 174.

[13]. Greenberg, A. E.; Clescari, L. S. and Eaton, A. D. (1992). Standard Methods for the Examination of water and waste water. $1^{\text {st }}$ ed. APHA-AWWA-WEF; Washington, D.C Pg 134.

[14]. Furma S. S. and Ogbeida, O. (1984). Chemical Characteristics of water in Bendel State of Nigeria. J. of Applied Science 2, Pg 6468.

[15]. WHO (2011). Standards and Guidelines. Available (online); http://www/WHO.int/en.htlm

[16]. Adepelumi, A; Ako, B. O.; Ajayi, I. P. (2001). Groundwater contamination in Basement complex area of lle Ife, Southweastern Nigeria: A case Study using the Electrical-Resistivity of Geographical Method Hydrogeology. Journal 9(6), Pg 611-622.

[17]. Crawford, M. D.; Gardner, M. J. and Morris, J. N. (1971). Brit Med. Bulletin, 21 Pg 21.

[18]. Okoye, C. O. B. and Nyiakaghe, T. D. (2009). Physico- Chemical Quality of Shallow well water in Gboko, Benue State, Nigeria. Bull. Chem. Soc. Ethiop 23 (1),Pg 128

[19]. Udeozo, P. I. and Ndeke, L. I. (2011). Physiochemical Analysis of Borehole water in Oba Idemili South, Anambra State, Nigeria. Anachem Journal vol. 5(1), 917-191. 